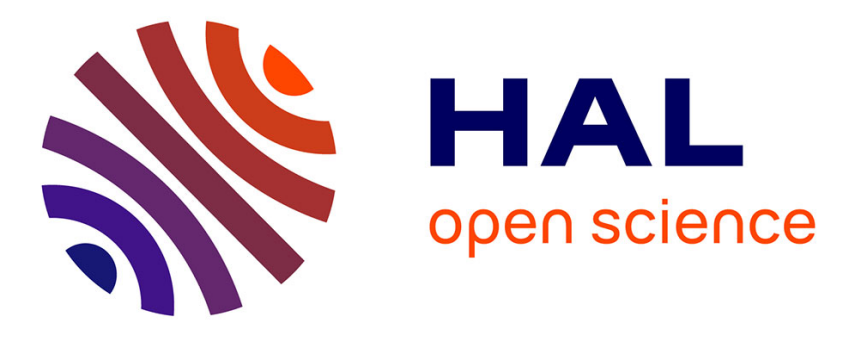

\title{
Genetic changes in Apis mellifera after 40 years of Africanization
}

Belén Branchiccela, Carlos Aguirre, Gloria Parra, Patricia Estay, Pablo Zunino, Karina Antúnez

\section{- To cite this version:}

Belén Branchiccela, Carlos Aguirre, Gloria Parra, Patricia Estay, Pablo Zunino, et al.. Genetic changes in Apis mellifera after 40 years of Africanization. Apidologie, 2014, 45 (6), pp.752-756. 10.1007/s13592-014-0293-2 . hal-01234776

\section{HAL Id: hal-01234776 https://hal.science/hal-01234776}

Submitted on 27 Nov 2015

HAL is a multi-disciplinary open access archive for the deposit and dissemination of scientific research documents, whether they are published or not. The documents may come from teaching and research institutions in France or abroad, or from public or private research centers.
L'archive ouverte pluridisciplinaire HAL, est destinée au dépôt et à la diffusion de documents scientifiques de niveau recherche, publiés ou non, émanant des établissements d'enseignement et de recherche français ou étrangers, des laboratoires publics ou privés. 


\title{
Genetic changes in Apis mellifera after 40 years of Africanization
}

\author{
Belén Branchiccela ${ }^{1}$, Carlos Aguirre ${ }^{2}$, Gloria Parra ${ }^{3}$, Patricia Estay $^{3}$, \\ Pablo Zunino ${ }^{1}$, Karina ANTÚNeZ ${ }^{1}$ \\ ${ }^{1}$ Departamento de Microbiología, Instituto de Investigaciones Biológicas Clemente Estable, Avda. Italia 3318, \\ 11600, Montevideo, Uruguay \\ ${ }^{2}$ Laboratorio de Biotecnología, INIA La Platina, Santa Rosa 11610, La Pintana, Santiago, Chile \\ ${ }^{3}$ Laboratorio de Entomología, INIA La Platina, Santa Rosa 11610, La Pintana, Santiago, Chile
}

Received 14 November 2013 - Revised 7 April 2014 - Accepted 2 May 2014

\begin{abstract}
The Africanization process of the honeybee Apis mellifera in America is considered one of the most spectacular biological invasions documented so far. It started in São Paulo (Brazil) in 1956 and the process has extended to almost all the continent (from the United States, to Argentina and Uruguay). The aim of this study was to evaluate the present status of Africanization in Uruguay after 40 years of its entrance, as well as to determine the circulating honeybee haplotypes through genetic (mitochondrial DNA) and morphometric approaches. Results showed that Africanized bees are completely established in Uruguay, representing $80 \%$ of the analyzed colonies, distributed throughout the whole country. A great genetic diversity was found, detecting eight different haplotypes. Some of them have been previously reported in the country, while others are new. The persistence of the non-African haplotypes in western provinces (Paysandú, Río Negro, Soriano and Colonia) may be due to a strong importation of European queens. This fact is probably avoiding the complete Africanization of the Uruguayan colonies.
\end{abstract}

\section{Africanization / Africanized honeybee / Apis mellifera / mitochondrial DNA / haplotype}

\section{INTRODUCTION}

The Africanization process of the honeybee Apis mellifera in America is considered one of the most spectacular biological invasions so far documented. This process started with the unplanned dispersion of African queens from Rio Claro (São Paulo, Brazil) in 1956. African bees were introduced in Brazil as an attempt to

Electronic supplementary material The online version of this article (doi:10.1007/s13592-014-0293-2) contains supplementary material, which is available to authorized users.

Corresponding author: K. Antúnez,

kantunez03@gmail.com

Manuscript editor: Marina Meixner obtain an organism well adapted to the Brazilian environmental conditions, in order to increase production rates (Kerr 1957). Since then, the $A$. mellifera scutellata queens have been hybridizing with local drones of European origin (Smith 1991) and the process has extended to almost the whole continent (from California, United States, to the Argentinian and Uruguayan provinces located between the $35^{\circ}$ and $40^{\circ}$ south latitude) (Abrahamovich et al. 2007; Kim and Oguro 1999; Sheppard et al. 1999).

In Uruguay, a country with 3,200 beekeepers and 500,000 colonies (MGAP 2012), local honeybees are hybrids generated by European honeybees (A. $m$. mellifera, brought to the country in the 1800s; Cordara 2005) and Africanized bees from Brazil (derived from 
Apis mellifera scutellata; Burgett et al. 1995; Diniz et al. 2003; Collet et al. 2006).

In previous studies, a latitudinal Africanization gradient was established according to the percentage of Africanized colonies and to the percentage of African genes present in the bee genome (Burgett et al. 1995; Diniz et al. 2003). Taking into account the intensive trading between beekeepers, it is possible to hypothesize that Africanized colonies have spread around the country.

The aim of this work was to evaluate the present status of Africanization in Uruguay as well as to identify circulating mitochondrial COI-COII haplotypes.

\section{MATERIAL AND METHODS}

\subsection{Samples}

Samples from all over the country were collected during March 2011. A total of 103 non-migratory apiaries were sampled, being the number of selected apiaries representative of the number of colonies registered in the National Register of Honeybee Colonies (DIGEGRA-MGAP). The number of colonies sampled per province was representative of the density of colonies per province.

One colony was randomly selected from each apiary. Adult bees were collected from peripheral combs, and stored in ethanol (70\%).

\subsection{Genetic characterization}

Taking into account that all the honeybees of each colony have inherited the same mitochondrial DNA, only one bee per colony was randomly selected and genetically characterized. The mitochondrial DNA was extracted using the protocol described by Walsh et al. (1991) with some modifications. One posterior leg was incubated at $37^{\circ} \mathrm{C}$ for $30 \mathrm{~min}$ to evaporate the residual ethanol. After that, $100 \mu \mathrm{l}$ of Chelex $5 \%$ (Sigma-Aldrich, SL, USA) and $5 \mu$ proteinase $\mathrm{K}$ solution $\left(20 \mathrm{mg} \mathrm{ml}^{-1}\right.$; Promega, Madison, WI, USA) were added and the sample was incubated for $1 \mathrm{~h}$ at $55^{\circ} \mathrm{C}, 15 \mathrm{~min}$ at $99^{\circ} \mathrm{C}, 1 \mathrm{~min}$ at $37^{\circ} \mathrm{C}$, and $15 \mathrm{~min}$ at $99^{\circ} \mathrm{C}$ (T1 Thermocycler; Biometra, Goettingen,Germany). Two microlitres of the DNA solution was used for the PCR amplification of the intergenic COI-COII region using the primers E2 (5'GGCAGAATAAGTGCATTG-3') and H2 (5'CAATATCATTGAT-GACC-3') (Garnery et al. 1992). The PCR mixture of $20 \mu$ contained $1 \times$ reaction buffer, $1 \mathrm{mM} \mathrm{MgCl} 2,0.15 \mu \mathrm{M}$ of each primer, $0.5 \mathrm{mM}$ of each $\mathrm{dNTP}$ and $0.5 \mathrm{U} / \mu \mathrm{l} \mathrm{Taq}$ polymerase (Invitrogen, Carlsbad, CA, USA). A negative control without DNA was included. The PCR cycling program included an initial denaturation step for $5 \mathrm{~min}$ at $94^{\circ} \mathrm{C}$, followed by 35 cycles of $45 \mathrm{~s}$ at $92^{\circ} \mathrm{C}, 45 \mathrm{~s}$ at $48^{\circ} \mathrm{C}, 2 \mathrm{~min}$ at $62^{\circ} \mathrm{C}$, and a final extension of $20 \mathrm{~min}$ at $65^{\circ} \mathrm{C}$ (T1 Thermocycler; Biometra) (Garnery et al. 1993). The size of the amplified DNA product was determined by electrophoresis in a $1 \%$ agarose gel, stained with GelRed (Biotum, Hayward, CA, USA) and visualized by UV light (T13; Biometra). Then, the product was digested with FastDigest DraI (Fermentas, São Paulo, Brazil) according to manufacturer's recommendations, analyzed by electrophoresis in a $12 \%$ polyacrylamide gel under native conditions for $15-16 \mathrm{~h}$ at $80 \mathrm{~V}$, and stained with GelRed (Biotium). Mitochondrial COICOII haplotypes were determined according to Franck et al. (1998). In those cases in which the haplotypes could not be clearly distinguished due to small differences in their restriction fragments size, PCR products were sequenced (Macrogen, Seoul, Korea). The identity of these haplotypes was confirmed through comparison with published sequences of the NCBI (National Center for Biotechnology Information), and $\mathrm{DraI}$ in silico restriction using BioEdit version 7.0.0 software (Ibis Biosciences, Carlsbad, CA, USA).

\subsection{Morphometric characterization}

Bees from colonies which showed a non-African origin after mitochondrial DNA analysis were morphometrically characterized using the FABIS method, a simple technique that allows the discrimination between African and European honeybees (Rinderer et al. 1987). In order to determine the Africanization probability, the average wing and femur lengths of ten bees were used.

The percentage of Africanized colonies was defined as the number of colonies which showed African origin (by genetic and morphometric analysis) in relation with the total colony numbers. 


\section{RESULTS}

In order to determine the percentage of Africanized colonies in Uruguay as well as the circulating honeybee mitochondrial haplotypes, a genetic and morphometric approach was performed including honeybee samples from all over the country.

The intergenic COI-COII region was amplified and 600 or 850 -bp products were visualized in all the samples (Supplementary material). After digestions of these products, different patterns were obtained.

Most of the patterns were associated with the African origin of the samples, with haplotype A4 being the most frequently detected
$(52.4 \%)$ as present in almost every province (Supplementary material) (Figure 1). Haplotypes A30 (16.5\%), A1 (9.7\%) and A26 (1\%) were also detected. The non-African haplotypes found were $\mathrm{C} 1(8.7 \%), \mathrm{C} 2$ (6.8\%), M4 (3.8 \%) and M7 (0.97\%) (Supplementary material) (Figure 1). Samples in which the haplotypes could not be clearly distinguished due to small differences in their restriction fragments size were sequenced and identified (Accession numbers KJ661741, KJ661742 and KJ661743).

Genetic analyses indicated that $79.6 \%$ (82 out of 103) of the analyzed colonies were Africanized. Since it is possible that the 21 remaining colonies inherited African characteristics by a paternal line (not represented in the

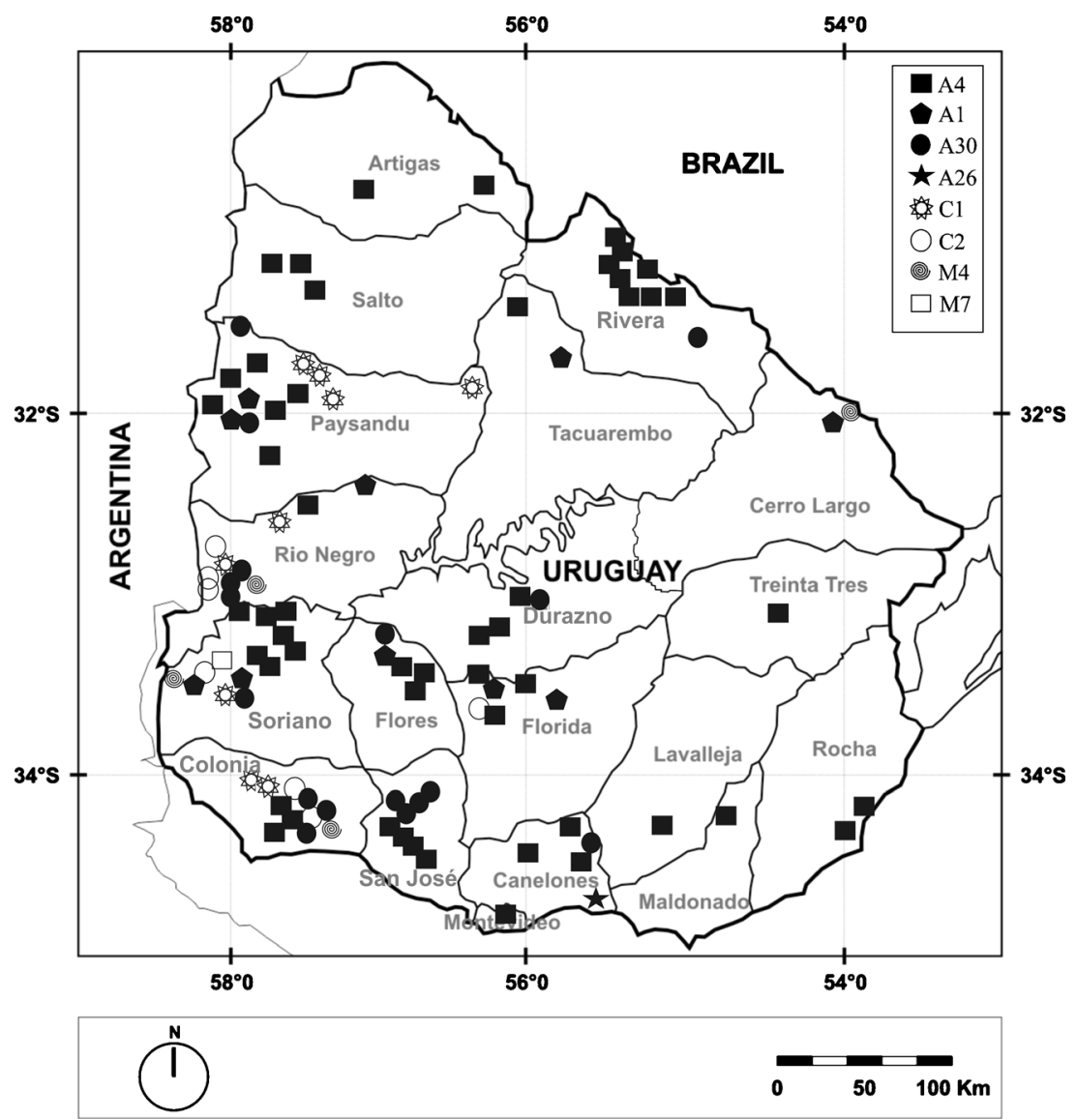

Figure 1 Geographic distribution of the Uruguayan honeybee mitochondrial COI-COII haplotypes. The black symbols represent the Africanized honeybees, while the white ones are the European haplotypes 
mitochondrial DNA), the African origin probability of these samples was calculated by a morphometric approach. All those samples presented $0 \%$ of an African origin probability, except one, which showed $65 \%$ of African origin probability taking into account the wing length, but a $3 \%$ of African origin probability considering together the wing and leg lengths.

\section{DISCUSSION}

In this study we determined that Africanized bees are completely established in Uruguay and widely distributed within the country, representing $80 \%$ of the colonies. A high genetic diversity was detected, including haplotypes from African and non African origins. Haplotypes A1, A4, A26, A30, C1 and M4 had already been described in our country a few years ago (Collet et al. 2006), while haplotypes $\mathrm{C} 2$ and M7 are described for the first time in Uruguay.

Haplotypes C1, A4 and A1 have been identified in close countries. However, their prevalence and distribution were quite different, which could reflect different colony management, and adaptation to the different environmental conditions. For example, in Buenos Aires (Argentina) most of the haplotypes corresponded to $\mathrm{C} 1(92.31 \%)$ and the African ones were in low proportion (5.02\%) (Abrahamovich et al. 2007). Haplotype A4 was the most common in Uruguay, Centre and South of Brazil, and Venezuela (Clarke et al. 2001), while it has been reported that A1 is one of the most common haplotypes in Mexico (Clarke et al. 2001). Collet et al. (2006) proposed the existence of a negative correlation between the latitude and the presence of $\mathrm{A} 1$ haplotype, which is in agreement with the low prevalence of this haplotype in Uruguay.

Geographic distribution of the mitochondrial COI-COII haplotypes in Uruguay was not uniform, as most of them (A4, A1, A30, C1, C2, M4 and M7) were concentrated in Paysandú, Río Negro, Soriano and Colonia. These provinces are located in the West region of the country, which is the main beekeeping area. Here, experienced beekeepers frequently import European honeybee queens (mainly $A$. mellifera ligustica) looking for behavioral and productive features, which could explain our results.

The loss of the latitudinal Africanization gradient from north to south observed by Sheppard et al. (1999) and Diniz et al. (2003), and the high Africanization rate detected in this study, can be explained by the commercialization of honeybee queens from Northern provinces (close to the border with Brazil) to the rest of the country.

For all these reasons, we suggest that the complete Africanization of the country is limited mainly by the artificial introduction of European honeybees. This is in accordance with Abrahamovich et al. (2007), who attributed the low level of Africanization in Buenos Aires province, Argentina, to the artificial introduction of Italian queens and selection programs in that country.

It would be interesting to evaluate if a gradual Africanization pattern (Sheppard et al. 1999; Diniz et al. 2003) persists when assessing the proportion of African alleles in the bee genome. In this aspect, a recent study based on Argentinean samples using SNPs, reported that there is still a north to south Africanization gradient (Whitfield et al. 2006).

In conclusion, the high Africanization percentage of Uruguayan honeybees reported here ( $80 \%)$ suggests that these bees have adapted to the country climatic conditions and that the beekeeping industry has become used to dealing with Africanized bees.

\section{ACKNOWLEDGEMENTS}

The authors thank Ciro Invernizzi, Gustavo Ramallo, the Apiculure section of INIA La Estanzuela (Colonia, Uruguay) and the AMSUD Pasteur Foundation.

Modifications génétiques chez Apis mellifera après 40 ans d'africanisation

Abeille africaine / haplotype / ADN mitochondrial / Amérique du Sud / Uruguay 
Genetische Veränderungen in Apis mellifera nach vierzig Jahren Afrikanisierung

\section{Afrikanisierung / afrikaniserte Honigbiene / mitochondriale DNA / Haplotyp}

\section{REFERENCES}

Abrahamovich, A.H., Atela, O., De la Rúa, P., Galián, J. (2007) Assesment of the mitocondrial origin of honey bees from Argentina. J. Apic. Res. and Bee World. 46, 191-194

Burgett, M., Shorney, S., Cordara, J., Gardiol, G., Sheppard, W.S. (1995) The present status of Africanized honey bees in Uruguay. Am. Bee J. 135, 328-330

Clarke, K.E., Oldroyd, B.P., Javier, J., Quezada-Euan, G., Rinderer, T.E. (2001) Origin of honeybees (Apis mellifera L.) from the Yucatan peninsula inferred from mitochondrial DNA analysis. Mol. Ecol. 10, 1347-1355

Collet, T., Ferreira, K.M., Arias, M.C., Soares, A.E.E., Del Lama, M.A. (2006) Genetic structure of Africanized honeybee populations (Apis mellifera L.) from Brazil and Uruguay viewed from mitochondrial DNA COICOII patterns. Heredity. 97, 329-335

Cordara, J.J. (2005) La Historia de la Apicultura en Uruguay. Facultad de Ciencias Agrarias. Universidad de la empresa, Montevideo, Uruguay

Diniz, N.M., Soares, A.E.E., Sheppard, W.S., Del Lama, M.A. (2003) Genetic structure of honeybee populations from southern Brazil and Uruguay. Genet. Mol. Biol. 26, 47-52

Franck, P., Garnery, L., Loiseau, A., Oldroyd, B.P., Hepburn, H.R., Solignac, M., Cornuet, J.-M. (1998) Genetic diversity of the honeybee in Africa: micro- satellite and mitochondrial data. Heredity. 86, $420-460$

Garnery, L., Cornuet, J.M., Solignac, M. (1992) Evolutionary history of the honeybee Apis mellifera inferred from mitochondrial DNA analysis. Mol. Ecology. 1, 145-154

Garnery, L., Solignac, M., Celebrano, G., Cornuet, J.M. (1993) A simple test using restricted PCR-amplified mitochondrial DNA to study the genetic structure of Apis mellifera L. Experientia. 40, 1016-1021

Kerr, W.E. (1957) Introduction of african honey bees in Brazil. Brasil Apicola. 3, 211-213

Kim, K.T., Oguro, J. (1999) Update of the Status of the Africanized Honey Bees of the Western States. West. J. Med. 170, 220-222

MGAP. (2012). Anuario 2012. www.mgap.gub.uy/

Rinderer, T.E., Sylvester, A., Buco, S.M., Lancaster, V.A., Herbert, E.W., Collins, A.M., Hellmich, R.L. (1987) Improved simple techniques for identifying Africanized and European honey bees. Apidologie. 18, 179-196

Sheppard, W.S., Rinderer, T.E., Garnery, L., Shimanuki, H. (1999) Analysis of the Africanized honey bee mitochondrial DNA reveals further diversity origin. Genet. Mol. Biol. 22, 73-75

Smith, D.R. (1991) African bees in the Americas: Insights from Biogeography and Genetics. Tree. 6, $17-21$

Walsh, P.S., Metzger, D.A., Higuchi, R. (1991) Chelex 100 as a medium for simple extraction of DNA for PCR-based typing from forensic material. Biotechniques. 10, 506-513

Whitfield, C.W., Behura, S.K., Berlocher, S.H., Clark, A.G., Johnston, J.S., Sheppard, W.S., Smith, D.R., Suarez, A.V., Weaver, D., Tsutsui, N.D. (2006) Thrice out of Africa: ancient and recent expansions of the honey bee, Apis mellifera. Science. 314, 642645 